\title{
Some Enzymatic Properties of Cathepsin A from Carp White Muscle*1
}

\author{
Kazushi Iwata*2, Noboru NAKAI*3, Kyoichi KoBASHI*3, \\ and Jun'ichi HASE*3
}

(Received August 5, 1976)

\begin{abstract}
Some enzymatic properties of the highly purified cathepsin A from white muscle of carp were examined. The optimal $\mathrm{pH}$ of the cathepsin A was 4.6 in $0.2 \mathrm{M}$ acetate buffer solution. Approximate $\mathrm{Km}$ values of the cathepsin A for carbobenzoxy (CBZ)-Glu-Phe, CBZ-Glu-Tyr and CBZ-Gly-Phe were $0.42,0.75$ and $14 \mathrm{~mm}$, respectively, in $0.2 \mathrm{M}$ acetate buffer solution, pH 5.0. Acetyl-Phe-Tyr $\left(\mathrm{I}_{2}\right)$ was hardly hydrolyzed by the enzyme. The thermostability of the enzyme was increased in the presence of $\mathrm{NaCl}$ and sucrose. $\mathrm{Hg}^{2+}, \mathrm{pCMB}$ and diisopropyl fluorophosphate were inhibitory on the enzymatic activity. The inhibition of the enzyme by antipain was competitive for CBZ-Glu-Tyr, with $\mathrm{K} i$ value of $17 \mu \mathrm{M}$. The enzymatic activity was inhibited by all the thiol compounds tested at high concentrations. Some discussions were presented as to whether carp cathepsin A and catheptic carboxypeptidase among cathepsins are the same enzyme or not. In the enzyme assay, the fluorometric method using fluorescamine showed some advantages to the conventional ninhydrin method in simplicity, rapidity, and sensitivity.
\end{abstract}

During the course of experiments on the role of proteins which induce "Modori" phenomenon in Kamaboko production, cathepsin A was highly purified from the white muscle of carp ${ }^{1}$.

Several investigations have been published on the purification procedures and enzymatic properties of cathepsin $\mathrm{A}$ in bovine spleen ${ }^{2,3)}$, chicken muscle ${ }^{2,4)}$, rat liver $^{5-9)}$ and pig kidney ${ }^{10-13)}$. It is of interest to compare with the enzymatic properties of cathepsin A from fish muscle and those from mammals.

In the present study, the highly purified cathepsin A from carp white muscle was examined on some enzymatic properties. The enzymatic activity was assayed by the usual ninhydrin colorimetric method as well as the fluorescence method using fluorescamine, a new reagent for the fluorometric detection of primary amine. ${ }^{14-15)}$.

\section{Experimental}

Carp cathepsin A Cathepsin A was prepared from the white muscle of carp, Cyprinus carpio, as described previously ${ }^{1}$. The final specific activity was $2.0 \mu$ mole of CBZ-Glu-

*1 This was presented at the 95th Annual Meeting of Pharmaceutical Society of Japan at Nishinomiya, April, 1975.

*2 Fuji Chemical Industries, Ltd., Chokeiji, Takaoka, Toyama Pref. (䂟田和士：䈏士萖品工業株式会社).

*3 Faculty of Pharmaceutical Sciences, Toyama Univ., Gofuku, Toyama, Toyama Pref. (中井年・小 橋恭一一長谷純一: 富山大学薬学部薬品生物化学教室). 
Tyr cleaved per min per mg of protein at $37^{\circ} \mathrm{C}$ and $\mathrm{pH} 5.0$ in $0.2 \mathrm{M}$ acetate buffer solution.

Materials N-Carbobenzoxy-L-glutamyl-L-phenylalanine (CBZ-Glu-Phe), N-carbobenzoxyl-L-glutamyl-L-tyrosine (CBZ-Glu-Tyr), N-carbobenzoxy-L-glycyl-L-phenylalanine (CBZ-Gly-Phe) were purchased from the Protein Research Foundation, Osaka. N-Acetyl-L-phenylalanyl-3, 5-diiodo-L-tyrosine [A-Phe-Tyr $\left(\mathrm{I}_{2}\right)$ ] was obtained from E. Merck AG. Darmstadt. Diisopropyl fluorophosphate (DFP) and L-1-tosylamido-2phenylethyl chloromethylketone (TPCK) were obtained from Sigma Chemical Co. and Seikagakukogyo, Tokyo, respectively. Antipain, [(S)-1-carboxy-2-phenylethyl] carbamoyl-L-arginyl-L-valyl-argininal ${ }^{16)}$, was generously provided from Dr. H. UMEZAWA of the Institute of Microbial Chemistry, Tokyo and fluorescamine, 4-phenylspiro[furan-2(3H), $1^{\prime}$-phthalan]-3, 3'-dione, was also obtained from the Roche Institute of Molecular Biology, New Jersey. p-Chloromercuribenzoic acid (pCMB) was used after purification according to the method of BOYER ${ }^{17)}$. Iodoacetic acid was recrystallized from chloroform. Other chemicals were of analytical grade. Solutions were prepared with deionized and distilled water obtained by all-glass apparatus.

Measurement of cathepsin $\mathbf{A}$ activity The enzymatic activity was measured by (1) the ninhydrin colorimetric method as described previously ${ }^{11}$ or (2) the fluorometric method in the following procedures. The reaction mixture consisted of $0.5 \mu \mathrm{g}$ of the enzyme protein, $1 \mathrm{mM}$ substrate and $0.2 \mathrm{M}$ acetate buffer, $\mathrm{pH} 4.7$ or 5.0 , and $0.1 \mathrm{M} \mathrm{NaCl}$ in the total volume of $0.5 \mathrm{ml}$, and was incubated at $37^{\circ} \mathrm{C}$ for $30 \mathrm{~min}$. The reaction was stopped by adding $2.2 \mathrm{ml}$ of $0.5 \mathrm{M}$ borate buffer, $\mathrm{pH} 8.5$. While mixing vigorously with a tube mixer at room temperature, $0.3 \mathrm{ml}$ of $0.03 \%$ fluorescamine solution in acetone was added using an autoburette. The reaction occurred within seconds at room temperature. Fluorescence was determined with a HITACHI Model 204 spectrofluorometer at excitation wavelength of $390 \mathrm{~nm}$ and emmission wavelength of $465 \mathrm{~nm}$. Tyrosine or phenylalanine was used as a standard compound under the same assay conditions. A blank was run by incubating the reaction mixture without substrate, followed by the addition of the borate and substrate at the end of the incubation period. The fluorescence intensity of the assay mixture was corrected by subtracting the blank intensity.

Determination of protein The protein concentration was determined either by microbiuret method ${ }^{18,19)}$ or the method of LowRY et al. ${ }^{20)}$ standardized with bovine serum albumin (Fraction V).

\section{Results and Discussion}

Effect of $\mathrm{pH}$ on the activity of cathepsin $\mathrm{A}$ The $\mathrm{pH}$-activity profile of cathepsin $\mathrm{A}$ for the hydrolysis of CBZ-Glu-Tyr was investigated using $0.2 \mathrm{M}$ acetate, $0.2 \mathrm{M}$ phosphate or Macllvaine buffer (Fig. 1). This enzyme showed the optimal activity at $\mathrm{pH} 4.6$ in acetate buffer and at $\mathrm{pH} 5.0$ in MacIlvaine buffer. At a neutral pH range, little activity 




Fig. 1.

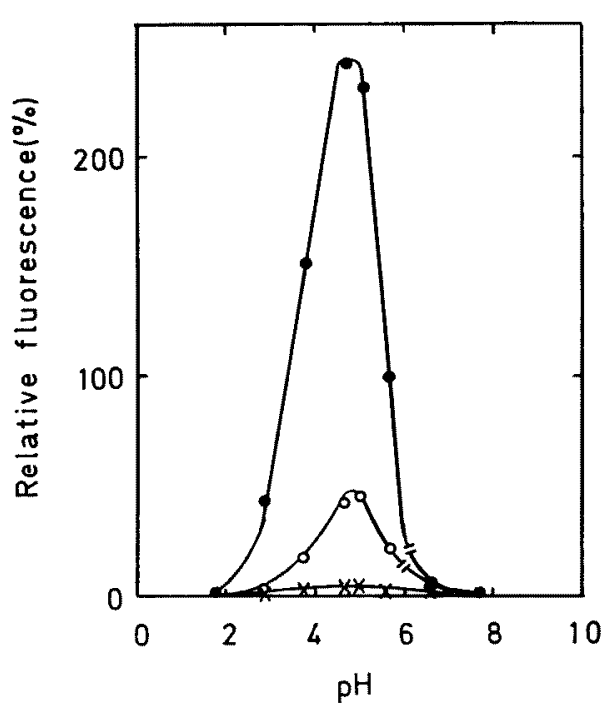

Fig. 2.

Fig. 1. Effect of $\mathrm{pH}$ on the hydrolysis of CBZ-Glu-Tyr by carp cathepsin A. $0.7 \mu \mathrm{g}$ of the enzyme protein was incubated at $37^{\circ} \mathrm{C}$ for $30 \mathrm{~min}$ in $0.5 \mathrm{ml}$ of the following buffer solutions containing $0.1 \mathrm{M} \mathrm{NaCl}$ and $1.0 \mathrm{~mm} \mathrm{CBZ-Glu-Tyr}$ at various pH's. The activity was estimated by the fluorescence method. The relative fluorescence was expressed by percentage of the fluorescent intensity of 20 nmole of tyrosine. Buffer system: $0.2 \mathrm{M}$ acetate$\mathrm{HCl}$ buffer from $\mathrm{pH} 1.8$ to $2.9 ; 0.2 \mathrm{M}$ sodium acetate-acetic acid buffer from $\mathrm{pH} 3.8$ to 5.7 (- - - $) ; 0.2 \mathrm{M}$ phosphate buffer from $\mathrm{pH} 6.6$ to 7.7 (- - ) or Macllvaine from $\mathrm{pH}$ 1.7 to $7.1(-x-)$.

Fig. 2. Effect of $\mathrm{pH}$ on the hydrolysis of CBZ-Glu-Phe, CBZ-Gly-Phe or A-Phe-Tyr $\left(\mathrm{I}_{2}\right)$ by carp cathepsin A.

$0.55 \mu \mathrm{g}$ of the enzyme protein was incubated at $37^{\circ} \mathrm{C}$ for $30 \mathrm{~min}$ in $0.5 \mathrm{~m} l$ of the following buffer solutions containing $0.1 \mathrm{M} \mathrm{NaCl}$ and $1.0 \mathrm{~mm}$ substrate at various $\mathrm{pH}^{\prime} \mathrm{s}$. The enzymatic activity was estimated by the fluorescence method. Buffer system: $0.2 \mathrm{M}$ acetate-HCl buffer from $\mathrm{pH} 1.8$ to $2.9 ; 0.2 \mathrm{M}$ sodium acetate-acetic acid buffer from $\mathrm{pH}$ 3.8 to 5.7 or $0.2 \mathrm{M}$ phosphate buffer from $\mathrm{pH} 6.6$ to 8.1 . The symbols were as follows: -1-CBZ-Glu-Phe, -O- CBZ-Gly-Phe, - $x-$ A-Phe-Tyr $\left(\mathrm{I}_{2}\right)$.

was observed in both buffers. As shown in Fig. 1, the activity in acetate buffer was about 6 times higher than that in Macllvaine buffer. This seems to indicate an inhibitory effect of citrate in the latter buffer. These observations accord substantially with the results by $\mathrm{DoI}^{10)}$ reporting that the activity of pig kidney cathepsin $\mathrm{A}$ was partially inhibited by citrate and also by phosphate. Consequently, acetate buffer was used hereafter. As shown in Fig. 2, the pH-activity curves of the enzyme for the hydrolysis of CBZ-Glu-Phe or CBZ-Gly-Phe weer similar to that for CBZ-Glu-Tyr, showing optimal pH to be 4.6 for both substrates. The optimal $\mathrm{pH}$ of the carp enzyme was slightly acidic than that $(\mathrm{pH}$ 5.2-5.9) of the enzyme obtained from internal organs of mammals ${ }^{9,13,13}$. A-Phe-Tyr $\left(I_{2}\right)$ which has been reported to be susceptible substrate for pepsin ${ }^{21}$ was hardly hydrolyzed by the carp enzyme. 
Cathepsin A was originally defined as the enzyme which hydrolyzes CBZ-Glu-Tyr, a synthetic substrate for pepsin and is not activated by the addition of thiol compounds. Therefore, this enzyme has been considered to be a pepsin-like endoproteinase ${ }^{22-25)}$. However, recent studies revealed that it is also one of carboxypeptidases ${ }^{2,12,13}$.

Approximate $\mathrm{Km}$ values of the carp cathepsin A for CBZ-Glu-Phe, CBZ-Glu-Tyr and CBZ-Gly-Phe were determined to be $0.42,0.75$ and $14 \mathrm{~mm}$, respectively in acetate buffer solution, pH 5.0. The affinity of the carp cathepsin A for CBZ-Gly-Phe was higher than that $(\mathrm{K} m=1.0-7.5 \mathrm{mM})$ of the enzyme from rat liver lysosome ${ }^{8,7,9,26)}$. However, the affinity of the carp cathepsin A for CBZ-Gly-Phe was slightly lower than that $(\mathrm{K} m=$ 5.4-10.6 mM) of the latter ${ }^{0,7)}$.

The concentration of amino acid liberated from synthetic substrates has been generally determined by the ninhydrin colorimetric method ${ }^{27}$ for the assay of cathepsin $\mathrm{A}$ or other peptidases. Fluorometric method using phthalaldehyde was presented by RoTH ${ }^{28}$ and TAYLOR et al. ${ }^{26)}$. Sensitive fluorometric method with fluorescamine on assay of trypsinlike protease was also reported by BROWN et al..$^{29}$ using herring protamine sulfate, as a substrate, which was blocked at the terminal amino group with dinitrofluorobenzene. Both fluorometries are known to be about one hundreds times more sensitive than the conventional ninhydrin colorimetry. However, the senstitivity of the fluorescamine procedure in our present study was much higher than that of phthalaldehyde procedure. Besides, fluorescamine procedure has advantages over the phthalaldehyde technique in lower background fluorescence of the reagents and comparatively little fluorescence as caused by ammonia.

Effect of temperature on the reaction and thermostability of the cathepsin $A$ The effect of the reaction temperature on the activity of the enzyme is shown in Fig. 3. The amount of product from $\mathrm{CBZ}-\mathrm{Glu}-\mathrm{Phe}$ incubated for $60 \mathrm{~min}$ was the highest at $50^{\circ} \mathrm{C}$. However, in presence of $0.5 \mathrm{M} \mathrm{NaCl}$ and $0.2 \mathrm{M}$ sucrose, as in the production of Kamaboko, the amount was the highest at $60^{\circ} \mathrm{C}$. When the enzyme solution was incubated without a substrate at $65^{\circ} \mathrm{C}$ for $40 \mathrm{~min}$, the activity was a little lost in the presence of $\mathrm{NaCl}$ and sucrose, but was remarkably lost in their absence (Fig. 4). These facts suggest that $\mathrm{NaCl}$ and sucrose protect the enzyme from heat inactivation.

Effect of various reagents on the activity of the cathepsin $\mathbf{A}$ Various metal ions such as $\mathrm{Mn}^{2+}, \mathrm{Ca}^{2+}, \mathrm{Mg}^{2+}$ and $\mathrm{Zn}^{2+}$ did not affect the activity, but $\mathrm{Hg}^{2+}$ and pCMB markedly inhibited the activity at $1 \mathrm{~mm}$, as shown in Table 1 . Metal chelators tested did not affect the activity either. The enzyme was partially inactivated by TPCK at $1 \mathrm{mM}$ and by antipain at $0.25 \mathrm{~mm}$. DFP completely inhibited the activity at $1 \mathrm{mM}$. It has been reported by Logunov et $a l^{3}{ }^{3}$, MATSUd et al. ${ }^{9}$ and $\mathrm{Dol}^{10)}$ that the activity of cathepsin A from bovine spleen, rat liver lysosome and pig kidney was markedly inhibited by $1 \mathrm{~mm}$ DFP. However, TAYLOR et al. ${ }^{7)}$ reported that DFP at a final concentration of $0.2 \mathrm{mM}$ activated the 


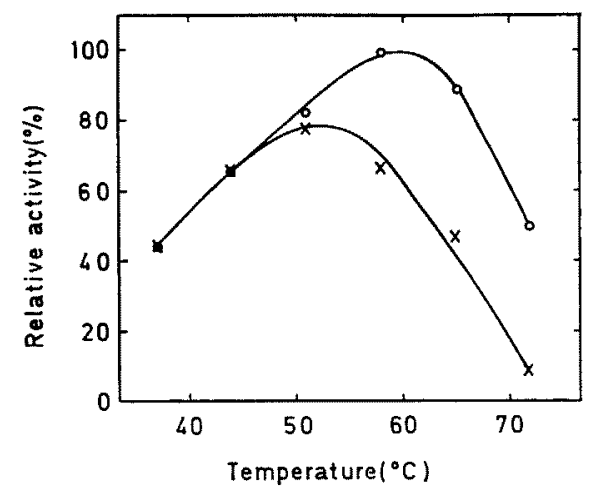

Fig. 3.



Fig. 4.

Fig. 3. Effect of temperature on the activity of carp cathepsin A.

$72 \mu \mathrm{g}$ of the enzyme protein in $1.0 \mathrm{ml}$ of $0.2 \mathrm{M}$ acetate buffer solution, $\mathrm{pH} 5.0$ containing $7.5 \mathrm{~mm} \mathrm{CBZ-Glu-Phe} \mathrm{was} \mathrm{incubated} \mathrm{with}(-\mathrm{O}-)$ or without $(-x-) 0.5 \mathrm{M} \mathrm{NaCl}$ and $0.2 \mathrm{M}$ sucrose at the indicated temperature for $60 \mathrm{~min}$. The activity was estimated by the ninhydrin colorimetric method ${ }^{1}$. The relative activities were expressed by percentage of the activity in the presence of $0.5 \mathrm{M} \mathrm{NaCl}$ and $0.2 \mathrm{M}$ sucrose at $58^{\circ} \mathrm{C}$.

Fig. 4. Effect of addition of $\mathrm{NaCl}$ and sucrose on the thermostability of carp cathepsin $\mathrm{A}$ at $65^{\circ} \mathrm{C}$. $200 \mu \mathrm{g}$ of the enzyme protein was preincubated in $0.5 \mathrm{ml}$ of $0.01 \mathrm{M}$ potassium phosphate- $0.005 \mathrm{M}$ sodium borate buffer, pH 6.6 containing $0.1 \mathrm{~mm}$ EDTA in the presence of $0.5 \mathrm{M} \mathrm{NaCl}$ and $0.2 \mathrm{~m}$ sucrose $(-\mathrm{O}-$ ) or in their absence $(-\times-)$. After preincubation the former mixture was diluted with $0.75 \mathrm{ml}$ of the same buffer solution and the latter with $0.75 \mathrm{~m} l$ of the same buffer solution containing $0.333 \mathrm{M} \mathrm{NaCl}$ and $0.133 \mathrm{M}$ sucrose. Therafter, $0.5 \mathrm{ml}$-aliquots were taken, followed by 120 min-incubation at $37^{\circ} \mathrm{C}$ with $0.2 \mathrm{ml}$ of $1 \mathrm{~m}$ sodium acetate-acetic acid buffer, pH 5.0 and $0.3 \mathrm{ml}$ of $25 \mathrm{~mm}$ CBZ-Glu-Phe. The phenylalanine liberated was estimated by the ninhydrin colorimetric method. ${ }^{1)}$

cathepsin A from rat liver lysosome to $120 \%$ of the control. The inhibition of the carp enzyme by antipain was shown to be competitive for CBZ-Glu-Tyr used as a substrate by Lineweaver-Burk plotting (Fig. 5), from which the $\mathrm{K} i$ value was found to be $17 \mu \mathrm{M}$ under the conditions as described in the legend of Fig. 5. MATsuda et al ${ }^{9}{ }^{9}$ reported that $100 \mu \mathrm{g} /$ $\mathrm{m} l$ of antipain was not inhibitory on cathepsin A purified from the lysosome fraction of rat liver. On the other hand, IKEZAWA et al. ${ }^{30)}$ reported that $\mathrm{ID}_{50}$ value of antipain was $1.19 \mu \mathrm{g} / \mathrm{ml}(2.0 \mu \mathrm{M})$ on cathepsin A activity in the acetone powder from lysosomalmitochondrial pellet of swine liver. The $\mathrm{K} i$ value of antipain for the carp enzyme was about 10 times larger than $\mathrm{ID}_{50}$ value reported by IKEZAwA et al. ${ }^{30}$. The effects of DFP and antipain on the cathepsin A so far reported were different from one another, probably due to different enzyme sources and purification (isolation) procedures.

Such sulfhydryl reagents as iodoacetamide and iodoacetate inhibited the activity at high concentrations, but the activity was not inhibited by $N$-ethylmaleimide at $10 \mathrm{~mm}$. It has been reported that cathepsin A from mammalian internal organs was not affected by 
Table 1. Effect of various reagents on the activity of cathepsin A. $0.5-0.6 \mu \mathrm{g}$ of the enzyme protein was preincubated in $0.45 \mathrm{ml}$ of $0.22 \mathrm{M}$ acetate buffer solution, $\mathrm{pH} 4.7$ containing $0.11 \mathrm{M} \mathrm{NaCl}$ and various reagents in an indicated final concentration at $37^{\circ} \mathrm{C}$ for $30 \mathrm{~min}$. The enzymatic activity was assayed by adding $50 \mu \mathrm{l}$ of $10 \mathrm{~mm} \mathrm{CBZ}-$ Glu-Tyr to the preincubation mixture. The tyrosine liberated was estimated by the fluorescence method.

\begin{tabular}{lcc}
\hline \multicolumn{1}{c}{ Compounds } & Concentrations & $10 \mathrm{mM}$ \\
\hline $\mathrm{None}$ & 100 & 100 \\
$\mathrm{MnCl}_{2}$ & 125 & 108 \\
$\mathrm{CaCl}_{2}$ & 118 & 104 \\
$\mathrm{MgCl}_{2}$ & 106 & 107 \\
$\mathrm{ZnCl}_{2}$ & 91 & 72 \\
$\mathrm{HgCl}_{2}$ & 15 & 0 \\
EDTA & 97 & 83 \\
o-Phenanthroline & 95 & 97 \\
$\mathrm{~K}_{3} \mathrm{Fe}(\mathrm{CN})_{8}$ & 80 & 21 \\
TPCK & 66 & 35 \\
DFP & 0 & 0 \\
Antipain & $50(0.25 \mathrm{mM})$ & - \\
Dithiothreitol & 82 & 9 \\
Mercaptopropionic acid & 77 & 17 \\
Thiomalic acid & 76 & 11 \\
2-Mercaptoethanol & 71 & 11 \\
Thioglycolic acid & 69 & 26 \\
Thiosalicylic acid & 60 & 7 \\
N-Ethylmaleimide & 92 & 92 \\
Iodoacetamide & 83 & 46 \\
Iodoacetic acid & 68 & 55 \\
pCMB & 21 & - \\
\hline
\end{tabular}

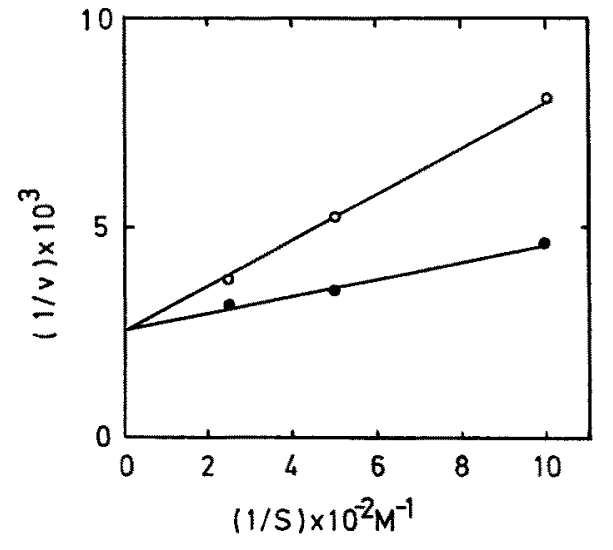

Fig. 5. Lineweaver-Burk plotting of CBZ-Glu-Tyr hydrolysis by the cathepsin $\mathrm{A}$.

$0.7 \mu \mathrm{g}$ of the enzyme protein in $0.5 \mathrm{~m} l$ of $0.2 \mathrm{M}$ sodium acetate-acetic acid buffer, pH 5.0, containing $0.1 \mathrm{M} \mathrm{NaCl}$ and the substrate was incubated with $(-\mathrm{O}-$ ) without $(-) 0.05 \mathrm{~mm}$ antipain at $37^{\circ} \mathrm{C}$ for $30 \mathrm{~min}$. The enzymatic activities were determined by the fluorescence method. thiol compounds ${ }^{7,9,10,12,13)}$, although the activity of catheptic carboxypeptidase from beef spleen $^{31,32}$ and rat liver lysosome ${ }^{6,33)}$ were accelerated by such compounds. The activity of carp cathepsin A was inhibited by all of the thiol compounds tested at high concentrations, as shown in Table 1. These observations accord substantially with the results by DoI et al. ${ }^{10,13)}$ reporting that the activity of pig kidney cathepsin A was partially inhibited by thiol compounds at $10 \mathrm{~mm}$.

Catheptic carboxypeptidase ${ }^{31,33 \text { ) }}$ is defined as the enzyme which 
hydrolyzes $\mathrm{CBZ}-\mathrm{Glu}-\mathrm{Tyr}$ at the optimal $\mathrm{pH}$ of 3.5, being activated by thiol compounds and inhibited by $\mathrm{pCMB}$ and iodoacetate. The catheptic carboxypeptidase has been considered to be distinguished from cathepsin $\mathrm{A}$ on the requirement of thiol compounds on activation and the optimal $\mathrm{pH}$, as described above. However, Dol et al. ${ }^{10,11)}$ discussed the possible identification of cathepsin $A$ as catheptic carboxypeptidase by the reasons that catheptic carboxypeptidase could not be separated from cathepsin A during the purification of proteolytic enzymes from pig kidney and that optimal $\mathrm{pH}$ of pig kidney cathepsin $\mathrm{A}$ was between 3 and 5 in the presence of sucrose and $\mathrm{KCl}$ in which that of catheptic carboxypeptidase is included. The activity of the carp enzyme was observed a little at $\mathrm{pH} 3.5$ in the presence of $0.1 \mathrm{M} \mathrm{NaCl}$, and was not affected by the addition of $10 \mathrm{~mm} 2$-mercaptoethanol. These observations suggest that carp cathepsin $\mathrm{A}$ is unequivocally discriminated from catheptic carboxypeptidase which is defined as described above. However, further examination has to be made as to whether cathepsin $\mathrm{A}$ and catheptic carboxypeptidase are the same enzyme or not.

\section{Acknowledgements}

We are indebted to Dr. H. UmEZAwa, Director of the Institute of Microbial Chemistry, Tokyo, for his kind supply of antipain and the Roche Institute of Molecular Biology, New Jersey, for kind gift of fluorescamine. Thanks are also due to Mr. K. Mitsu for his helpful suggestions.

\section{References}

1) K. Iwata, K. Kobashi, and J. Hase: This Bull., 43, 181-193 (1977),

2) A. A. Iodice: Arch. Biochem. Biophys., 121, 241-242 (1967).

3) A. I. Logunov and V. N. ORekhovich: Biochem. Biophys. Res. Commun., 46, 1161-1168 (1972).

4) A. A. Iodice, V. LeONG, and L. M. WeInstock: Arch. Biochem. Biophys., 117, 477-486 (1966).

5) E. Misaki and A. L. TAppel: Comp. Biochem. Physiol, 38B, 651-662 (1971).

6) S. L. TAYlor and A. L. TAPPEL: Biochim. Biophys. Acta, 341, 99-111 (1974).

7) S. L. TAYLOR and A. L. TAPPEL: ibid., 341, 112-119 (1974).

8) K. MAtsuda and E. Misaka: J. Biochem, 76, 639-649 (1974).

9) K. Matsuda and E. Misaka: ibid., 78, 31-39 (1975).

10) E. DOI: ibid., 75, 881-887 (1974).

11) E. Doi, Y. Kawamura, T. Matoba, and T. Hata: ibid., 75, 889-894 (1974).

12) Y. Kawamura, T. Matoba, T. Hata, and E. Dol: ibid., 76, 915-924 (1974).

13) Y. Kawamura, T. Matoba, T. Hata, and E. Doi: ibid., 77, 729-737 (1975).

14) M. Weigele, S. L. DeBernardo, J. P. Tengi, and W. Leimgruber: J. Am. Chem. Soc, 94, 59275928 (1972).

15) S. Udenfriend, S. Stein, P. Böhlen, W. Dairman, W. Leimgruber, and M. Weigele: Science, 178, 871-872 (1972).

16) S. Umezawa, K. Tatsuta, K. Fujmoto, T. Tsuchiya, H. Umezawa, and H. Naganawa: J. Antibiotics, 25, 267-270 (1972).

17) P. D. BoYer: J. Am. Chem. Soc., 76, $4331-4337$ (1954).

18) R. F. Itzhaki and D. M. GiLl: Anal. Biochem., 9, 401-410 (1964).

19) S. UMemoto and K. KANNA: Bull. Tokai Reg. Fish. Res. Lab., 56, 109-116 (1968). 
20) O. H. Lowry, N. J. Rosebrough, A. L. FarR, and R. J. Randall: J. Biol. Chem., 193, 265-275 (1951).

21) W. T. JACKSON, M. Schlamowirz, and A. Shaw: Biochemistry, 4, 1537-1543 (1965).

22) J. S. Fruton and M. Bergmann: J. Biol. Chem., 130, 19-27 (1939).

23) J. S. Fruton, G. W. IRVING, JR., and M. BergmanN: ibid., 138, 249-262 (1941).

24) J. S. Fruton, G. W. Irving, JR., and M. Bergman: ibid., 141, 763-774 (1941).

25) H. H. Tallan, M. E. Jones, and J. S. Fruton: ibid., 194, 793-805 (1952).

26) S. L. TAXLOR and A. L. TAPPEL: Anal. Biochem., 56, 140-148 (1973).

27) H. Rosen: Arch. Biochem. Biophys., 67, 10-15 (1957).

28) M. Roth: Anal. Chem., 43, 880-882 (1971).

29) F. Brown, M. L. Freed, and W. Troll: Biochem. Biophys. Res. Commun., 53, $75-81$ (1973).

30) H. Ikezawa, K. Yamada, T. Aoyagi, T. Takeuchi, and H. Umezawa: J. Antibiotics, 25, 738-740 (1972).

31) L. M. Greenbaum and R. Sherman: J. Biol. Chem., 237, 1082-1065 (1962).

32) L. M. Breenbaum and K. Yamafuj: Life Sci, 4, 657-663 (1965).

33) A. Mellors: Arch. Biochem. Biophys., 144, 281-285 (1971). 